\title{
The Selfish Skald: The Problematic Case of the Self of the Poet of Sonatorrek
}

\begin{abstract}
The poem Sonatorrek, a poem on the loss of kin, attributed to the tenthcentury skáld Egill Skalla-Grimsson, is the object of this study. The main objective of the first part of the article is to discuss the methodological problems related to discerning the context where the poem was composed. The attributions of the poem to the tenth century poet Egill, as well as to the thirteenth-century context of the composition of his saga, are difficult to sustain from the extant seventeenthcentury manuscript material. We must therefore consider at least three possible contexts for the composition of the poem. From this reasoning it is clear that we cannot establish with any certainty whether the representation of self in the extant text witnesses should be regarded as part of a tenth-, a thirteenth-, or even a seventeenth-century context. The second part of the article treats Sonatorrek as a representation of self, set in the various contexts that can be discerned from the sourcecritical discussion.
\end{abstract}

Keywords: skaldic poetry, sagas of skalds, oral poetry, manuscript culture, source criticism

The poem Sonatorrek, a poem on the loss of kin attributed to the tenth-century skáld Egill Skalla-Grimsson and usually read in connection with the prose narrative about the poet, Egils saga Skalla-Grimssonar, is the object of this study. The main objective concerns the methodological problems related to discerning the context where the poem was composed. The attribution to the Viking Age poet Egill, as well as the medieval context of the saga, are difficult to establish with any certainty. We must consider at least three possible contexts at widely different points in time for the composition of the poem: first, the tenth century of Egill himself, where the context is established with the help of the thirteenth-century saga; second, the thirteenth century of the saga writer, which would indicate that the poem was composed either in the allegedly oral tradition about the old poet or as part of creating the narrative about him; or third, the only context where the poem is extant today, the seventeenth-century manuscripts named Ketilsbækur (AM 453 4to and AM 462 4to). A central task for anyone who wishes to study the

Karl G. Johansson, University of Oslo

Ә Open Access. (C 2020 Karl G. Johansson, published by De Gruyter. (cc) BY-NC-ND This work is licensed under a Creative Commons Attribution-NonCommercial-NoDerivatives 4.0 International License. 
representation of the self in historical material in general, arguably, must be to discuss the implications of the state of the preservation in order to contextualize the material. This is definitely the case concerning Sonatorrek. These issues will be addressed in the first part of this article.

The second part of the article will consider Sonatorrek as a representation of self, set in the various contexts that can be established from the extant information. Can the representation of a self related to any particular context in space and time in the poem be established with any certainty? Arguably, we need to address the question of whether the representation of self that appears in the extant text witnesses should be regarded as part of a tenth-, a thirteenthor even a seventeenth-century context. It should be stated here that, obviously, this study should be seen as highly tentative. It must also be made clear at this point that, when whatever obstacles of time and state of the extant material are satisfactorily removed, it is still not certain what representation of self is actually encountered. The poet is in any instance an individual with a personal objective with his poem, whether he is called Egill Skalla-Grímsson or considered to be a later, but still impressive poet.

\section{Sonatorrek and Its Context(s)}

In most cases, skaldic poetry is today found in relation to prose narratives about Norwegian kings (Kings' sagas) and Icelandic individuals and families (Sagas of Icelanders). The poems, however, are considered to be written down from a long oral tradition and incorporated into the prose narratives only at a later stage in the thirteenth century. A skaldic poem is generally composed in a highly complicated form and the imagery is rather accomplished. This makes it plausible, according to the prevailing opinion among scholars, to think that the poems have survived the long period of oral transmission more or less unchanged. It is important to point out, however, that the poem under investigation here is not composed in the complicated meter of dróttkvætt but in the considerably more open meter of kvíðuháttr.

There are a number of methodological problems challenging the scholar who is interested in the representation of the self as found in the Old Norse poetry. The first obstacle to be treated here has to do with the transmission of the poems allegedly composed by poets in an oral tradition from the tenth and eleventh centuries. This obstacle needs to be seen in stages. First, we need to ask ourselves if the poems really are from these ancient days and from a long and undisturbed oral tradition. It goes without saying that this first problem is in itself more or less 
unsolvable, as oral tradition per definition is a rather mute source, but it nevertheless needs to be addressed. A second problem concerns the poetic tradition in manuscript culture. In the context where a modern reader encounters the poems, they are merged with prose narratives, in the kings' sagas relating the stories of how poets entered the courts of kings and made their fortune there, or in the Sagas of Icelanders where the poets themselves are central, e.g., Egill SkallaGrímsson in Egils saga Skalla-Grimssonar or Kormákr in Kormáks saga. ${ }^{1}$ An a priori understanding of the alleged tenth-century poets' representation of their selves arguably could not be based on these narratives from the thirteenth or even fourteenth centuries; in order to understand the Viking Age poets, we need to base our analysis rather on the poems themselves, and attempt to free our reading from what we know from the narratives.

An often neglected, or even unacknowledged obstacle to our understanding is found in the various modern editions of the extant poetry. The attributions of poems to individual poets are made in the saga narratives, and it is most likely that this is where a reader first encounters the poetry of the skálds. This means that, at the outset, a modern reader has already formed a first impression from the prose narrative context. Is it at all possible to free oneself from the narrative in Egils saga about Egill's loss of two sons and how he was persuaded by his daughter to compose an elegy for them, an erfikvæði? But the editions of the poems as separate entities, such as Finnur Jonsson's from the early twentieth century or the new edition currently being published, also take as a starting point the attributions to individual poets provided by the sagas. Further, the collection of poems in print as a modern book of poetry does not enhance our understanding of the oral culture where they were allegedly composed.

In the medieval context of the saga about Egill, as will be seen below, there are only a few traces of what we call Sonatorrek, as it is only preserved to a large extent in much later manuscripts. But in the editions of the saga, as well as in editions of separate poems, it is presented as a full, medieval poem.

It could also be relevant to ask who, in the tenth or eleventh century, would have known all these poems and remembered all the attributions to earlier poets? Was there ever a "reader" of skaldic poetry who resembled the modern scholar? All too often, this oral tradition is understood from a rather anachronistic perspective where texts are considered to be available in a canon, a situation hardly

1 The anthology Skaldsagas: Text, Vocation, and Desire in the Icelandic Sagas of Poets edited by Russell Poole (2001) provides many insightful and relevant chapters by leading scholars on the problems related to skaldic poetry in the saga context. 
applicable to the late-Viking Age tradition. This last methodological problem leads to an issue of a more theoretical nature concerning our understanding of concepts such as poet, poetry, and the central concept of our book, that is, the self. When aware of the methodological obstacles mentioned above, this must also lead to an awareness of the otherness of both the distant oral tradition of the poets (or perhaps rather the context of poets in this tradition) and the manuscript tradition in which one encounters the narratives as well as the poems in writing. Therefore this question of otherness must be addressed before taking at face value any statements that seem to provide presentations of a self in the poetry.

The poem Sonatorrek is, as mentioned above, today extant only in two post-Reformation paper manuscripts, the so called Ketilsbækur, AM 453 4to and AM 462 4to, dated to the seventeenth century and produced by Árni Magnússon's maternal grandfather, Ketill Jörundsson. ${ }^{2}$ A single stanza (st. 1) is extant in the codex usually forming the base for editions of Egils saga SkallaGrimssonar, Möðruvallabók, AM 132 fol, dated to c. 1330-1370. Another two stanzas are preserved in manuscripts of the prose Edda and with attributions to Egill Skalla-Grimsson (st. 22 and 23). ${ }^{3}$ All text witnesses to the stanzas in the prose Edda are dated to the fourteenth century or later.

The relation between the extant poetry and the various contexts can be illustrated in the Stemma Carminis as in Fig. 1, below. Here, the earliest contexts must be no more than hypothetical. The oral state of the poem cannot be established with any certainty from the extant written sources. Only two full stanzas and four lines of a third are represented in medieval manuscripts, in all cases with clear reference to the saga poet Egill Skalla-Grimsson. In the text witness to Egils saga Skalla-Grimssonar in Möðruvallabók (AM 132 fol), it is stated that Egill was persuaded to compose a poem for his two dead sons:

Egill s(eger) at pat var pa vuænt at hann munde pa yrkia mega pott hann leitaðe við. En freista ma ek pess s(eger) hann. Egill hafði pa átt son er Gvnnarr het ok hafði sa ok andaz litlu aðr. Ok er petta upphaf kuæðis.

(Egils saga A, 149)

[Egill says that it should not be expected that he would have the power to compose even if he tried. But I will try, he says. Egill had a son called Gunnarr and he had also died a little earlier. And this is the beginning of the poem.]

(My translation)

This statement is followed by the first stanza. The two stanzas found in the manuscripts of the prose Edda are, as mentioned, attributed to Egill by the

2 For a thorough description of these manuscripts, see Egils saga $C$, xxiii-xxxvi.

3 Only lines 1-4 of stanza 23 are extant in this source. Note that the numbering of the stanzas of Sonatorrek throughout this chapter follows that of the edition in Egils saga C. 
surrounding prose (see Skáldskaparmál, 9) with the short phrase "Sva kvað Egill Skallagrímsson" (Egill Skalla-Grímsson composed) but with no reference to a poem called Sonatorrek. From the medieval evidence, it can therefore safely be concluded that there was a tradition for attributing these three stanzas to Egill, even if it was not necessarily to the poem Sonatorrek. This does not, however, mean that the rest of the stanzas could be attributed to the same poet, even if the seventeenth-century manuscripts where the poem is presented in full suggest that the whole poem at one point in time has been considered his composition. It is interesting to note that the latter manuscripts actually have a similar phrase referring to an introductory stanza as Möðruvallabók, even though it presents a full poem. The question is what implications this should have for our contextualization of the poem. It has been suggested that the poem as we find it in AM 453 4to and AM 462 4to is based on an exemplar going back to $c .1400$ (see, e.g., IF 2, 245, n. 1). In the apparatus of the recent edition of $\mathrm{C}$, the editor concludes that "kun 1. strofe af kvadet Sonatorrek citeres i A og B; resten må være interpoleret i arketypen ${ }^{\star} \mathrm{C}$ el. en efterkommer deraf, allersenest $i$ hyparketypen ${ }^{\star} c^{1} .{ }^{4}$ This would indicate that this lost codex either introduced the full poem without changing the introductory phrase or that the poem was introduced later, possibly even in direct connection with the rewriting in the two extant Ketilsbækur. The implications of this could be twofold. Either the poem as we know it has never existed in a medieval written form and was added to the saga narrative at a later state, or it had existed in a medieval manuscript used as one of the exemplars for the re-writing of the saga in Ketilsbækur or their exemplar, where one of the exemplars had the phrase followed by the first stanza while the other exemplar had the full poem. If the first alternative is chosen, this could indicate that the full poem is a rather late addition to the tradition. If, on the other hand, the poem in full is assumed to have been extant in one of the exemplars for Ketilsbækur or in an earlier exemplar, the question must be addressed why the phrase indicating a single stanza has been kept. $^{5}$

4 "Only the 1st stanza of the poem Sonatorrek is quoted in A and B; the rest must be interpolated in the archetype ${ }^{\star} \mathrm{C}$ or a later copy of it, at the latest in the hyparchetype ${ }^{\star} \mathrm{C1}$ " (Egils saga C, 142-3; my translation).

5 The phrase "Ok er petta upphaf kuæðis" introducing a single stanza (Norse lausavísa) or a single introductory stanza, as in Sonatorrek, has been thoroughly treated by Judy Quinn (1997). See also Margaret Clunies Ross for a treatment of the poetry in Egils saga in relation to the narrative prose (2010). 
The state of the extant text witnesses and the implications of speculations of later text critics are very well described by Russell Poole in a recent article:

Only two witnesses of the complete poem have survived, both very late, and the text they supply is evidently in a badly damaged and garbled state. It may also be, as Hollander suggested, that the poem was difficult even for contemporaries of its author, perhaps as a calculatedly virtuoso piece. Additionally, there is the distraction caused by nineteenthand twentieth-century text critical adventurism: critics routinely cite passages from the purported text that are little more than free-ranging fantasies on the part of such scholars as Finnur Jónsson, E. A. Kock, Hallvard Lie and Magnus Olsen.

(Poole 2010, 173)

Poole goes on to argue for the historical Egill Skalla-Grimsson as the poet responsible for composing the poem. He contends that Egill (based on references to the saga) could have been "representative of his class," influential in Iceland and with claims in Norway, active as "a mercenary fighting on various sides in England and Denmark, and as an iterant poet” (Poole 2010, 176). Poole further accepts the saga narrative's tale of Egill's relation to the Anglo-Saxon king Æthelstan as an indication that "the historical Egill" was well aware of Christian ideas of the tenth century and would have been able to transform those ideas into the kviðuháttr of Sonatorrek (Poole 2010, 183-99). The Christian influences that he distinguishes do not, according to Poole, point in the direction of a later time of conception, but rather must be seen as early contacts with Christians by a "historical Egill" in the tenth century (see, e.g., Poole 2010, 193-4). ${ }^{6}$

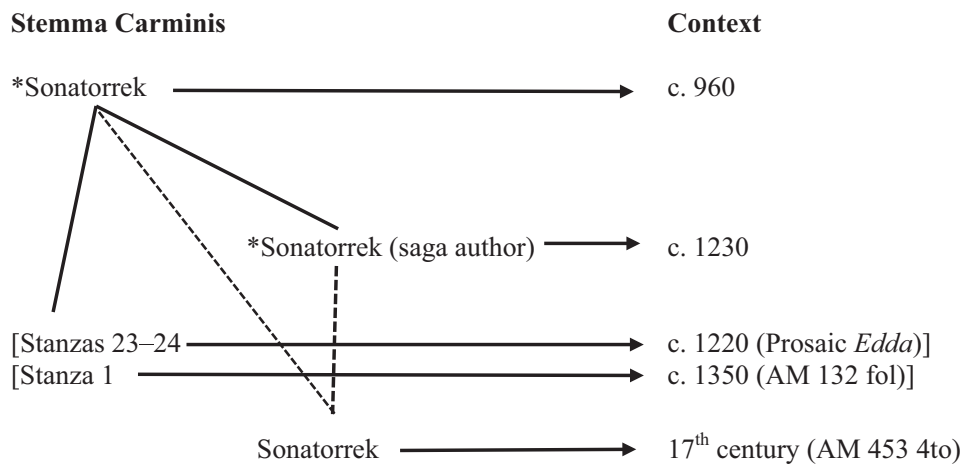

Fig. 1: Stemma Carminis and the possible contexts of Sonatorrek.

6 If the relations between Sonatorrek and tenth- and eleventh-century poetry from AngloSaxon England noted by Russell Poole are seen in the light of what we know about the earliest period of writing in the vernacular in Iceland and Norway, i.e., the twelfth and early thirteenth century, this could indicate a completely different, but possible implication of his reasoning. It could be argued that these Anglo-Saxon poetics, as well as Christian 


\section{Earlier Views of Sonatorrek and the Skald}

In the scholarship of Sonatorrek, there have been many different views on its status and how it could be interpreted. The standard appreciation of the poem considers it to be a lamentation over the lost son(s). None of the interpretations, however, have been done independent of the prose narrative; it seems that no one ever doubted this narrative about the events that lead up to the composition of the poem that the saga itself refers to as Sonatorrek. An example of this steady belief in the saga narrative in which the poem has been embedded can be found in Daniel Sävborgs statement:

Ett verk av Egill utmärker sig i fråga om sorg framför alla andra. Det gäller Sonatorrek, diktad ca 960 med anledning av två av Egills söners död. Sonatorrek är en regelrätt sorgdikt; det är sorgen som är dess huvudtema från första till sista (25:e) strofen.

(Sävborg 1997, 134)

[One work by Egill is exceptional in its expression of sorrow. That is Sonatorrek, composed around 960 in relation to the death of the two sons of Egill. Sonatorrek is a lamentation after the book; sorrow forms the main theme from the first to the last (25.) stanza.]

(My translation)

The scholar seems here to take the saga account almost at face value. It is therefore interesting to note how this effects the evaluation of the poem as an expression of grief, the traditional understanding. If we scrutinize the poem we find, however, that the poem itself does not mention the two sons by name and it does not really express any deeper sorrow; it is only in the narrative context of Egils saga Skalla-Grimssonar that the deaths of Boððvarr and Gunnarr are recounted, whereas the poem itself rather focuses on the poet's position and loss of control. The narrator relates the long story of how Boðvarr drowns and how this leads Egill to withdraw into his sleeping chamber to starve himself to death, and how his daughter Porgerðr persuades him to compose the poem. And then, as if by some afterthought, it is stated that "Egill hafði pá átt son, er Gunnarr hét, ok hafði sá ok andazk litlu áðr” (Egill had another son named Gunnarr who had also died a little earlier) (ÎF 2, 245). Was this son added just to comply with the plural of the name Sonatorrek, or was the death of Gunnarr perhaps less dramatic? After the first stanza, the narrative states that Egill got better and that he "lét [. . . erfa sonu sína eptir fornri siðvenju" (arranged the inheritance after his sons according to the old customs) (If 2, 257). Again, the plural is marked to comply with the poem seemingly mentioning two sons.

ideas, were most likely influential in the twelfth century when the earliest vernacular texts were composed. 
An earlier example of this acceptance of the saga narrative can be found in the work of Sigurður Nordal (1924), who argues that the poem relates the personal crisis of Egill after the loss of sons, and the poet's way of healing himself. His reasoning is based on the prose narrative without even addressing the possibility of it being a later fiction.

The perspective of healing is also dealt with by Bo Ralph. He analyzes the poem as it relates to religious beliefs and argues that it represents a time when skaldic poetry was strongly connected with religious practices. Ralph places the poet and his skills in a mythic-religious context in the pre-Christian period. In his introduction to the reasoning, Ralph does argue that the prose narrative should not be taken at face value, but still the pre-Christian (or "pagan") religious beliefs that he suggests are based on this text composed in the thirteenth century not on the supposedly Viking Age poem. This leads him to draw conclusions from written sources formed in a Christian context in the same way as most earlier scholars. In his further discussion, Ralph often, against his own statement, returns to the saga narrative for supportive arguments. It turns out that it is difficult not to be influenced by the narrative that is so well known to the scholar.

Ralph makes an important point that Boðvarr (who is not mentioned by name in the poem, only in the prose narrative) is not the theme of the poem, but that it rather is Egill himself who is the focus (but it could be objected that Egill is not mentioned in the poem, only the anonymous poet (ek), and his habitus can only be established from the prose narrative):

Huvudsyftet är inte att hugfästa den unge Bǫðvars duglighet. Dikten är ett vittnesmål om Egils eget sista desperata försök att återupprätta sin ställning som magiker; han vill återfå förmågan att påverka de metafysiska krafterna.

(Ralph 1976, 164)

[The main objective [of the poem] is not to establish the abilities of the young Boðvarr. The poem is a witness to Egill's last and desperate attempt to re-establish his position as a magician; he wishes to regain his ability to steer the metaphysical powers.]

(My translation)

I agree with Ralph that we need to analyze the poem separately but cannot see that he actually manages to follow this intention. Further, I also agree with Ralph that the poem has its own poet (or poets) as the main object of interest. The dead kin are only mentioned as loss of support and position, not as missed persons.

Torfi H. Tulinius (2004) would rather place the poet in a thirteenth-century European tradition and argues $(2004,112)$ that a thirteenth-century poet trained in the tradition as described in the prose Edda could very well have composed the poem in the place of Egill Skalla-Grimsson. The individual sorrow and positioning of the poet would then rather be seen as a thirteenth-century sentiment or, perhaps more correctly, a reconstruction of what a thirteenth-century 
person thought would be representative of a tenth-century poet. By 2001, Torfi $\mathrm{H}$. Tulinius had pointed out biblical references in the poem. It is interesting to note, however, that he more or less concludes that the saga writer is identical to the poet, which would explain the intertextuality between the poem and the surrounding prose (see, e.g., 2001, 215). He concludes:

Given the reasonable doubt exists as to the poem's pagan status and taking into account the significance the saga author seems to have ascribed to Egill's life story, especially the way he models him partly on the figure of King David, it is noteworthy that twelfthcentury Latin poetry includes works composed in the name of male figures from the Old Testament.

(Torfi H. Tulinius 2001, 215)

Given that Torfi H. Tulinius argues for a dating of the poem contemporary to the saga narrative, it is of course reasonable to look for the relation between prose and poetry as parts of an original composition. It does not, however, exclude the possibility of understanding the poem as a considerably later composition added where the original writer had only planned to provide a single introductory stanza, as the preceding prose suggests.

More recently, Joseph Harris (2010) has discussed the poem in relation to myths from the perspective of Mircea Eliade. He argues for cautiousness due to the state of the text but concludes that we should not be overly cautious.

Caution is in order, but too much caution is paralysing, and after all Egill did leave a very large corpus of poetry, in which his own voice speaks across the ages, preserved in oral tradition until recorded in writing at various times. Among the few items of Egill's surviving oevre that have been reasonably suspected of later authorship, Sonatorrek does not number - for most scholars.

(Harris 2010, 153)

Harris argues for a reading of the narrative context as representative of some kind of memory of myth and ritual. This is arguably problematic and rather difficult to sustain when the discrepancies between narrative and poetry are taken into account. It is, for example, interesting that there is no mention of either Bǫðvarr or Gunnarr in the poem itself. There are no names mentioned from the saga context whatsoever. And perhaps even more problematic: Egill's kin is not at all coming to an end if we are to believe the saga narrative, as his third son Porsteinn is alive and well. Harris has a problem concerning how to define the poem generically. He states: "Egill's poem may anticipate nineteenth-century lyrical sensibilities, but it, like every work of art, must also be a product of its time" (Harris 2010, 156). This is relevant in relation to the representation of self. The poet seems to express individual feelings, lyrical sensibilities that would not be expected in literary compositions of the pre-modern period. On the other hand, this could possibly be a reflection of a poet not too much affected by Christian piety. But again, the elegiac aspects of the poem are problematic; rather, the poet 
expresses a self that is occupied primarily by the rational aspects of its own pain, loss, and the problems caused by the death of the son and other family members. His main objective seems to be to position himself and his own importance.

In 2015, a full volume, Egil, the Viking Poet (Looze et al. 2015) was dedicated to an examination of the poet Egill Skalla-Grimsson and his poetry. Here a number of scholars discussed the self of the Viking Age poet (e.g., Clunies Ross 2015; Looze 2015). Yet it may be maintained that it is still problematic to move beyond the written evidence, and it is obvious from the contributions to this volume that there is no consensus among scholars about the provenance and role of poetry in the saga (see, e.g., Torfi H. Tulinius 2015).

\section{Sonatorrek Revisited}

The extant poem found in Ketilsbækur consists of 24 stanzas where the edition in Íslensk fornrit divides the poem into 25 stanzas. As pointed out by Russell Poole (2010), the status of the preserved text is problematic to say the least, and in many cases later text criticism has made emendations that most scholars today accept (often without even realizing the problem) when interpreting the poem. The second stanza provides good examples of this.

2. Egils saga C (143) Edition in IF 2 (246-7)

$\begin{array}{ll}\begin{array}{ll}\text { Era andpeizt } \\ \text { pvïat ecke velldur }\end{array} & \text { Esa auðpeystr, } \\ \text { pvít ekki veldr } \\ \text { haufuglegr } & \text { hǫfugligr, } \\ \text { ür higgju stad } & \text { ór hyggju stað } \\ \text { fagna fundr } & \text { fagna fundr } \\ \text { priggja nidja } & \text { Friggjar niðja } \\ \text { ärborinn } & \text { ár borinn } \\ \text { ür iọtun heimum } & \text { ór Jǫtunheimum. }\end{array}$

[It is not easily forced from the place of thought - sorrow is the cause - the poetry, borne long ago from the land of giants.] (My translation of the IF text)

In Lexicon Poeticum (LP, 23), Finnur Jónsson makes a reference from andpeyst (normalized form of andpeizt as found in the manuscript) to auðpeystr, where he states the meaning as "let at sætte i stærk fart" (easy to bring in high speed) without mentioning that this later form actually is based on his own emendation in $S k j$ B I (34). The word that is found in the manuscript would mean something like 
"speed against," which makes less sense in the overall interpretation on which Finnur Jónsson based his emendation. It is interesting to note, however, that neither the form found in the manuscript nor the one suggested by Finnur Jónsson is found in other instances; both are hapax legomena, one of them found in a seventeenth-century manuscript, the other created by a twentieth-century philologist!

The second marked word in the example, "priggja" (three), is emended in the manuscript to Friggjar by Finnur Jonsson, introducing the goddess Frigg in a kenning Friggjar niðjar referred to in Lexicon Poeticum as an existing kenning (found only in Sonatorrek as edited by Finnur Jónsson, but treated as an authentic kenning in $L P, 427)$. Would the original form of the manuscript make any sense? The second part of the stanza could be translated as "the joyful meeting of three kinfolk early carried from Jotunheim." This introduces a group of kinfolk that would need to be interpreted. Perhaps a possible solution could be sought in the prose Edda, where there are a number of examples of three gods involved in processes of creation or origin, for example, Óðinn, Vili, and Vé (Gylfaginning 1988, 11-13) in the creation of the world and the first humans. Another possible interpretation of the kenning could be related to what is recounted about the creation and retrieving of the poetic mead from the giant Suttungr in Skáldskaparmál (3-5). The mead is poured into three vessels, Óðreyrir, Són, and Boðn, by two dwarfs before it is given to Suttungr. Óðinn, using the name Bolverkr, arrives at the place Suttungr is and obtains the mead through foul play and brings it to the gods. The prose Edda states:

En Suttungs mjǫð gaf Óðinn Ásunum ok peim mọnnum er yrkja kunnu. Pví kọllum v[ér] skáldskapinn feng Óðins ok fund ok drykk hans ok gjǫf hans ok drykk Ásanna.

(Skáldskaparmál, 5)

[And Óðinn gave Suttung's beer to the Æsir and those men who could compose poetry. Therefore, we call poetry the catch of Óðinn or his meeting or drink or gift and the drink of the Æsir.]

(My translation)

It is interesting to note here that the prose Edda actually suggests a kenning Óðins fundr, which could have been expected in stanza 2. It could be argued that, according to the rules for kennings offered by the prose Edda, the name of Óðinn could be exchanged with any name of the Æsir, e.g., Frigg, and this is most likely the foundation for Finnur Jónsson's emendation.

Whatever solution we choose for these specific problems of reading and interpreting the poem, it should be obvious from the single example of stanza 2 that we are very often on shaky ground when using the edited text of, e.g., Íslenzk fornrit as a base for our understanding. In the following, with this in mind, the edited text will still be supplied parallel to the text from the $\mathrm{C}$ redaction of Egils saga for the sake of availability; it is, however, important to remember the premises for my 
reading, that this edited text in itself is a new version of the poem that has very little evidence in the medieval material.

If we now take a first look at the poem as a whole as it is, in fact, found only in Ketilsbækur, the first thing that should be mentioned is the textuality of the presentation. The poem consists of 24 stanzas that are clearly forming a concluded text. This indicates a literate approach to the composition rather than an oral one, with stanzas providing an introduction to the theme, and stanzas making a clear close of the poem that echo the introductory stanzas.

The first two stanzas present the situation of grief. The poet mentions as early as the first line how difficult it is for him to express himself. The poetic lament is hard to bring forward for the one who has lost his kin. These two stanzas, together with the last three stanzas (23-25), form the outer frame of the poem. Together they provide what appears to be a coordinated introduction and conclusion of the text Sonatorrek. The first two stanzas and the last two are presented here to illustrate how even the wording is similar in the first and the last stanza.

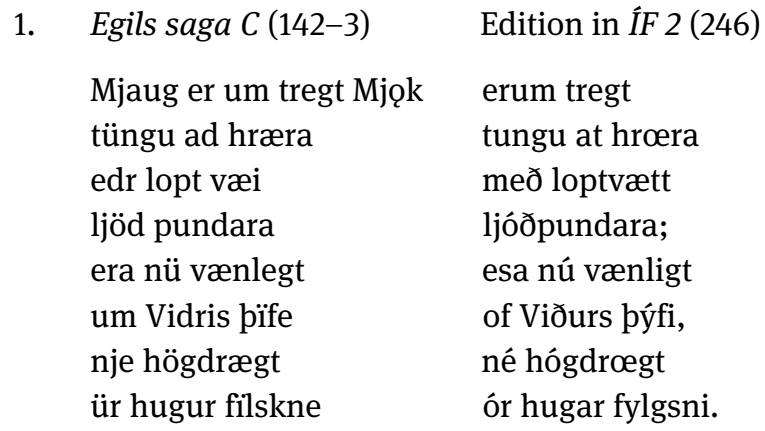

[It is very hard for me to move my tongue in composing a poem; it is not a good time for poetry nor is it easy to force it out of the mind's storage.]

(My translation)

In the very first line, the poet focuses on his own problem of composing the lament in poetry. There is no indication as to why he has this difficulty of finding poetic expression. It is only from the preceding prose that we know that Egill Skalla-Grímsson has lost not only his favorite son Boððvarr, but also another son called Gunnarr. There is just a small emendation made by Finnur Jónsson in this stanza. In line 3, the reading is lopt væi rather than loptvætt as in the IF edition. In $L P$, Finnur Jónsson explains the emendation as just another form of the same hapax legomenon. The line of thought is continued in the second stanza. 
2. Egils saga C (143)

Era andpeist

pvïat ecke velldur

haufuglegr

ür higgju stad

fagna fundr

priggja

ärborinn

Ür Jǫtun heimum
Edition in IF 2 (246-7)

Esa auðpeystr,

pvít ekki veldr

hǫfugligr,

ór hyggju stað

fagna fundr

nidja Friggjar niðja

ár borinn

e ór Jotunheimum.

[It is not easily forced from the place of thought - sorrow is the cause - the poetry, borne long ago from the land of giants.]

(My translation)

Here sorrow is mentioned for the first time, but not the cause of this sorrow. The focus here is instead on the poetic expression and the difficulty of composing. As demonstrated above, the understanding of this stanza is based on the emended text found in modern editions, but even when the manuscript text is revisited, the general understanding of the stanza is not significantly altered if we leave out the emendation of the kenning introducing the goddess Frigg.

The two last stanzas of the poem seem to form a sequel to the first two stanzas. Here the poet returns to the importance of poetic expression and its role in his life.

23. Egils saga $C$ (148)

Gäfunzt iprot

ülfs og bage

vïge vanur

vamme firda

og pad gjed

er eg gjørda mjer

vïsa fjandr

ad velaundum
Edition in IF 2 (256)

Gǫfumk íprótt

ulfs of bági

vígi vanr

vammi firða

ok pat geð,

es gerðak mér

vísa fjandr

af vélǫndum.

[Óðinn, experienced in battle, gave me the art that strikes at slander and the temper that provided open enemies for false friends.] (My translation)

In this penultimate stanza, poetry is presented as a gift to the poet from Óðinn ["bági úlfs" (the enemy of the wolf)]. The poet states that he received the gift and that it has helped him in making open enemies of false friends. No word here about the lament of dead kin. The last stanza has its focus on the poet and his own death. 
24. Egils saga C (148)

Nü er mjer torvellt

Tveggja baga ${ }^{7}$

njørfa nipt

ä nesin stendr

skal eg pö gladur

med gödan vilja

og öhriggr

heljar bïda
Edition in IF 2 (256)

Nú erum torvelt,

Tveggja bága

njǫrva nipt

á nesi stendr,

skalk pó glaðr

góðum vilja

ok óhryggr

heljar bíða.

[It is hard for me as Hel stands on the narrow peninsula; but gladly and with a positive mind I will wait for my death.]

(My translation)

If the four stanzas are seen from a structural perspective, it is clear that they are composed to match each other. The introductory stanza states that "Mjok erum tregt" to compose poetry while the last stanza states that "Nú erum torvelt" to live on, but still the poet will stand content and glad in wait of his own death. The second stanza (in whichever reading we choose, revised or not) further stresses the difficulties of the poet in gaining his inspiration. This is mirrored in the second to last stanza (23) where the gift of poetry is celebrated as a way to stand firm: the poet has regained his ability to compose. This frame embeds the rest of the poem that is more focused on the deaths in the family and their implications for the poet. It is soon clear, however, that, rather than contemplating the death of kin, the poem is focused on the poet's own loss of support and people to defend his honor.

It is only in the third stanza that the death of a son is explicitly mentioned. There is not much said of him, however; he seems rather to be an object lost to the father than a loved person. Finnur Jónsson has made no significant changes in this stanza.

3. Egils saga C (143)

Edition in IF 2 (247)

Lastalauss

lastalauss

er lifnade

es lifnaði

ä nocckvers

á nǫkkvers

nøckva brage

nǫkkva bragi;

Jøtuns häls

Jotuns hals

7 The edition has a comment: "baga] sål. (ved konjektur) K2; boga (!) K1 825” (2006, 148-9). 


$\begin{array}{ll}\text { under flota } & \text { undir pjóta } \\ \text { näins nidur } & \text { náins niðr } \\ \text { firer naust dirum } & \text { fyr naustdyrum. }\end{array}$

[When without guilt the son lay on the cold peninsula, the wind of the sea howls around my dead son's grave on the beach.]

(My translation)

From the following stanza 4, the poem turns back to the poet and his loss. First, the end of kinship is lamented. The man who has to bury his own son (or rather: kin) is the important person here, not the dead kin. The focus turns to the poet and his sorrow, rather than to the loss of a beloved son. And in subsequent stanzas, the focus is even more on the poet and his loss of support. The son would have become a good man as he was the son of the poet.

\begin{tabular}{|c|c|}
\hline Egils saga C (145) & Edition in IF 2 (250) \\
\hline $\begin{array}{l}\text { Veit eg pad själfr } \\
\text { at ï sine mïnum } \\
\text { var`a` ills pegns } \\
\text { efne vaxid } \\
\text { ef sä randvidr } \\
\text { rauskvazt næde } \\
\text { uns hergautz } \\
\text { hendr of tæke }\end{array}$ & $\begin{array}{l}\text { Veitk pat sjalfr, } \\
\text { at í syni mínum } \\
\text { vasa ills pegns } \\
\text { efni vaxit, } \\
\text { ef randviðr } \\
\text { røskvask næði, } \\
\text { uns hergauts } \\
\text { hendr of tœki. }\end{array}$ \\
\hline
\end{tabular}

[I know myself that nothing bad would have come from my son if he had grown to maturity before Óðinn retrieved him.]

(My translation)

And consequently, the son was primarily important as he supported his father without question. This is further treated in stanza 12.

12. Egils saga C (145) Edition in ÍF 2 (250)

$\begin{array}{ll}\text { Æ ljet flest } & Æ \text { lét flest } \\ \text { pad er fader mællte } & \text { pat’s faðir mælti, } \\ \text { pött øll pjöd } & \text { pótt oll bjóð } \\ \text { annad segde } & \text { annat segði, } \\ \text { og mjer upphjellt } & \text { mér upp helt } \\ \text { um verberge } & \text { of herbergi } \\ \text { og mitt afl } & \text { ok mitt afl } \\ \text { mest um studde } & \text { mest of studdi. }\end{array}$


[He always heeded his father's word even when others disagreed; he helped me at home and supported my strength.]

(My translation)

In stanza 19, what seems to be a second son is mentioned. It could be the case, however, that the poet is still contemplating the same son and that stanza 19 is only a variation of the theme found in stanzas 11 and 12. The change from vammavanr in the $C$ version to vamma vanr in the $I F$ edition only slightly changes the meaning of the stanza.

19. Egils saga $C$ (147) Edition in ÍF 2 (254)

$\begin{array}{ll}\text { Sïzt son minn } & \text { síz son minn } \\ \text { söttar brïme } & \text { sóttar brimi } \\ \text { heiptuglegr } & \text { heiptugligr } \\ \text { ür heime nam } & \text { ór heimi nam, } \\ \text { pann eg veit } & \text { panns ek veit } \\ \text { ad varnade } & \text { at varnaði } \\ \text { vammavar } & \text { vamma vanr } \\ \text { vid nämæle } & \text { við námæli. }\end{array}$

[Since my son left this world, taken by the hard disease, I know that he avoided evil and stood against slander.]

(My translation)

The variation of the theme of the good son is continued in stanza 20, where Ódinn is presented as the god who took the son away from the parents.

20. Egils saga C (147) Edition in ÍF 2 (254-255)

$\begin{array}{ll}\text { Pad man eg enn } & \text { Pat mank enn, } \\ \text { er upp um höf } & \text { es upp of hóf } \\ \text { ï god heim } & \text { í Goðheim } \\ \text { Gauta spjalle } & \text { Gauta spjalli } \\ \text { ættarask } & \text { ættar ask, } \\ \text { pann er } & \text { öx af mjer panns óx af mér, } \\ \text { ok kin vid } & \text { ok kynvið } \\ \text { kvonar minnar } & \text { kvánar minnar. }\end{array}$

[I do remember when Óðinn took him to the world of gods, the limb of kin grown from me, the branch of my wife's family.]

(My translation) 
It is interesting to note here that, following Finnur Jónsson's reading, Óðinn ["Gauta spjalli" (the confidante of the Gotar) ${ }^{8}$ would lead to the interpretation that Óðinn has received the son who died from a disease, which again would not be in line with the mythology underlying skaldic imagery; the one who dies from disease would rather be received by Hel. The next thing to consider, therefore, is the poet's positioning in relation to the gods. There is really just one god mentioned in the poem, Óðinn, who was, according to the prose Edda, the leading god and also the god of the skalds. It would therefore not be surprising to find him in this context. But there are also references in the poem to two supernatural beings related to the sea, Rọn and Ægir.

In stanza 7, Rọ́n is said to have taken away all of the beloved ones from the poet. It is again interesting to note that the relationship is between the sea-goddess and the poet. Much has been taken away from me ("rysktan mik") and I am bereft ("emk ofsnauðr") of all whom I loved. And all is because of Rọ́n, who (as a personification of the sea) has riven the rope of my kin ("minnar ættar"), a hard knot of myself ("snaran pǫtt af sjǫlfum mér”).

7. Egils saga C (144)

Mjauk hefur Rän

riskt um mig

em eg ofsnaudr

at ästvinum

sleit mars bond

minnar ættar

«snaran〉 pätt

af själfum mjer
Edition in IF 2 (248)

Mjǫk hefr Rọ́n

of rysktan mik;

emk ofsnauðr

at ástvinum;

sleit marr bond

minnar ættar,

snaran pćtt

af sjollfum mér.

[Rọ́n has taken much from me, I have lost all I ever loved. The sea broke all ties of kin, a hard rope of myself.]

(My translation)

Even Óðinn is accused of betrayal by the poet. He states that he had a good relationship with Óðinn until the god betrayed their friendship. The focus yet again is on the poet and his relation to the god; no mention here of the dead sons.

8 It should be noted that Finnur Jónsson's reading "Gautar" (m.pl.) (gotar) here is only one of two possible readings. A second reading, "Gauti” (m.sg.) (Óðinn), is also possible but would be problematic if the kenning is interpreted as "Óðinn"; this reading would lead instead to an interpretation of "Gauta spjalli" as "the confidante of Óðinn" = "warrior." 
21. Egils saga C (147-148)

Ätta eg gott vid geira drottinn gjørdunst triggr ad trüa hanum ädr umat vagna runne sigur haufundr um sleit vid mig
Edition in ÍF 2 (255)

Áttak gótt við geirs dróttin, gerðumk tryggr at trúa họnum, áðr vinan vagna rúni sigrhǫfundr of sleit við mik.

[I was living well with the god of the spear [Óðinn], it felt secure to trust in him, before the friendship was broken by the victorious god.] (My translation)

In the penultimate stanza (23), which in many ways form a part of the frame mentioned earlier, the poet still praises Óðinn for the gifts he has received from him. The god has provided him with the art of poetry (or of the word), which betrays false friends and makes them open enemies. So, once again, the poet is the focus.

If we return, finally, to the last stanza (24), we see the poet once again complaining about his own difficulties, but now he has regained his courage and is willing to fight on in good will (gódum vilja). This last expression has been mentioned as a Christian phrase, found in texts from the thirteenth century and later (see, e.g., Torfi H. Tulinius 2004). This could at least indicate that the frame could be a later addition to make the poem a closed text with Christian references, but it could also indicate a considerably later date than the tenth century for the whole poem.

\section{Conclusion}

In conclusion, it is time to further investigate the contexts suggested by the above discussion in order to gain insight into how the representations of self could be situated. There is little support for placing the poem in the tenth century when it was allegedly composed. Egill Skalla-Grímsson may very well have been a historical person and poet, but the saga composed more than two centuries later provides a fictional portrait of him. If poetry contemporary to the Viking Age Egill is examined (which is, however, found in similar contexts and with similar source critical problems), the corpus does not provide any parallels to Sonatorrek. When the poets allegedly composing stanzas or longer poems in the tenth century mention themselves, it is generally in relation to a king or powerful chieftain. More intimate references are rare or more or less unseen in the extant material. This indicates 
that Egill would be a strange exception in this period if he composed a poem of this kind. As Russell Poole (2010) has argued, we would need to go outside of the Norse material to find contemporary parallels, for example, in the Anglo-Saxon poetry of the time.

The strongest argument for Sonatorrek being a pre-Christian poem would be that it refers to a world of "heathen" gods and uses kennings based on what seems to be a Viking Age poetic tradition. This argument is weakened by the appearance of similar kennings and use of mythology in thirteenth- and even fourteenth-century poetry in dróttkvætt. It could also be argued that the presentation of Norse poetics and mythology found in the prose Edda attributed to Snorri Sturluson indicates that it would not necessarily be a "pagan" poet who composed a poem like Sonatorrek; the poet could just as well have been a contemporary of Snorri and of the author of Egils saga Skalla-Grimssonar, as argued by, for example, Torfi H. Tulinius (2001, 2004).

It would be tempting, therefore, to suggest that the poet Egill and his poetry are the result of a thirteenth-century narrator's creation of a tenth-century narrated self, a poet with "pagan" attributes, but still reminding the narrator and his intended audience of their own time and milieu. This would lead us back to the saga narrative and allow us to understand the poem as part of the fiction created by a thirteenth-century narrator rather than as a tenth-century expression of an itinerant and violent warrior poet, as suggested by Poole (2010).

As I have demonstrated above, however, the medieval tradition as it is present in the fourteenth-century manuscript Möðruvallabók (AM 132 fol) indicates that only the initial stanza was preserved in relation to the saga narrative. This could lead us to conclude, on the one hand, that the medieval scribes and the saga author who mention only the single stanza in the text leading up to the first stanza did not know the rest of the poem or, on the other hand, that the poem was considered to be so well known that it did not need to be written down; everyone who read or heard the saga would know it by heart when the first stanza was presented. The latter explanation cannot be sustained in any extant contemporary discussions of poetry and the performance of poems. Rather, it seems likely that the author has chosen to provide only a single stanza, either because he had no interest in the poetic tradition or because he actually did not know the full poem. It is also interesting that the C version of Egils saga Skalla-Grimssonar that does contain the whole poem extant today still introduces the poem with only mentioning the introductory stanza, as if the exemplar (or its exemplar) did in fact contain no more than this single stanza.

For the sake of argument, therefore, it is relevant to address the question of whether Sonatorrek as it exists today, extant only in a seventeenth-century context, should be analyzed primarily in relation to the expression of self in this late period; 
all other contexts would be formed based on speculation rather than extant material. However, it must be made clear that, to my knowledge, there is no evidence or even any indication (except in the state of preservation) of the largest part of the poem being a seventeenth-century amendment in order to provide a full poem. Linguistically, the poem seems to be too well formed as a medieval (or even Viking Age) composition to be the work of a seventeenth-century antiquarian. If it were, it would have to be assumed that this seventeenth-century antiquarian was well read in Norse metrics and poetics. It would also imply that, rather than expressing his own self, the poet would have aimed at representing what he considered the expression of sorrow and loss of a Viking Age poet. It should be stated, therefore, that the poem as it is preserved most likely represents a late, perhaps late medieval, understanding of the Viking Age poet and his expression of self. It might also be the case that the seventeenth-century antiquarian introduced the full poem from another source in order to present the poet's self-expression to a new audience in a new time and perhaps also in a new intellectual context. My conclusion must be that the representation would not be that of a seventeenth-century poet, but it would still provide interesting insights into the antiquarian interests of this period.

\section{References}

\section{Primary Sources}

Egils saga $\mathrm{A}=$ Egils saga Skallagrímssonar. Bind 1, A-redaktionen. 2011. Ed. Bjarni Einarsson. Editiones Arnamagnæanæ, Series A, 19. Copenhagen.

Egils saga $\mathrm{C}=$ Egils saga Skallagrímssonar. Bind 3, C-redaktionen. 2006. Ed. Michael

Chesnutt. Editiones Arnamagnæanæ, Series A, 21. Copenhagen.

Skáldskaparmál = Snorri Sturluson. Edda. Skáldskaparmál. 1998. Ed. Anthony Faulkes. London.

Skj. = Den Norsk-Islandske Skjaldedigtning, A: Tekst efter håndskrifterne, vol. 1-2, B: Rettet tekst, vol. 1-2. 1912-1915. Ed. Finnur Jónsson. Copenhagen.

Gylfaginning = Snorri Sturluson. Edda. 1988. Ed. Anthony Faulkes. London.

ÍF 2 = Egils saga Skalla-Grímssonar. 1933. Ed. Sigurður Nordal. Íslenzk fornrit 2. Reykjavík.

\section{Secondary Sources}

Clunies Ross, Margaret. 2010. “Verse and Prose in Egils saga Skallagrímssonar." In Creating the Medieval Saga. Ed. Judy Quinn and Emily Lethbridge. The Viking Collection, 18. Odense. 191-211. 
Clunies Ross, Margaret. 2015. "Self-description in Egil's Poetry." In Egil, the Viking Poet: New Approaches to Egil's Saga. Ed. Laurence de Looze et al. Toronto Old Norse-Icelandic Series. Toronto. 75-91.

Harris, Joseph. 2010. “'Myth to Live By' in Sonatorrek.” In Laments for the Lost in Medieval Literature. Ed. Jane Tolmie and M. J. Toswell. Medieval Texts and Cultures of Northern Europe, 19. Turnhout. 149-71.

Looze, Laurence de. 2015. "The Concepts of the Self in Egil's saga: A Ricoeurean Approach.” In Egil, the Viking Poet: New Approaches to Egil's Saga. Ed. Laurence de Looze et al. Toronto Old Norse-Icelandic Series. Toronto. 57-74.

Looze, Laurence de, Jón Karl Helgason, Russell Poole, and Torfi H. Tulinius, eds. 2015. Egil, the Viking Poet: New Approaches to Egil's Saga. Toronto Old Norse-Icelandic Series. Toronto.

$L P=$ Lexicon Poeticum antiquæ linguæ septentrionalis. Ordbog over det norsk-islandske skjaldesprog. Ed. Finnur Jónsson. København.

Poole, Russell, ed. 2001. Skaldsagas: Text, Vocation, and Desire in the Icelandic Sagas of Poets. Ergänzungsbände zum Reallexikon der Germanischen Altertumskunde, 27. Berlin.

Poole, Russell. 2010. “'Non enim possum plorare nec lamenta fundere': Sonatorrek in a TenthCentury Context til minningar um Stefán Karlsson." In Laments for the Lost in Medieval Literature. Ed. Jane Tolmie and M. J. Toswell. Medieval Texts and Cultures of Northern Europe, 19. Turnhout. 173-99.

Quinn, Judy. 1997. “'Ok er petta upphaf' - First-stanza quotation in Old Norse Prosimetrum.” Alvíssmál 7: 61-80.

Ralph, Bo. 1976. “Om tillkomsten av Sonatorrek.” Arkiv för nordisk filologi 91: 153-65.

Sävborg, Daniel. 1997. Sorg och elegi i Eddans hjältediktning. Stockholm Studies in History of Literature, 36. Stockholm.

Sigurður Nordal. 1924. “Átrúnaður Egils Skallagrímssonar.” Skírnir: 145-65.

Torfi H. Tulinius. 2001. "The Prosimetrum Form. 2. Verses as the Basis for Saga Composition and Interpretation." In Skaldsagas: Text, Vocation, and Desire in the Icelandic Sagas of Poets. Ed. Russell Poole. Ergänzungsbände zum Reallexikon der Germanischen Altertumskunde, 27. Berlin. 191-217.

Torfi H. Tulinius. 2004. Skáldid i skriftinni. Snorri Sturluson og Egils saga. Reykjavík.

Torfi H. Tulinius. 2015. "The Construction of Egils saga." In Egil, the Viking Poet: New Approaches to Egil's Saga. Ed. Laurence de Looze et al. Toronto Old Norse-Icelandic Series. Toronto. 23-39. 
